\title{
Artikel Manajemen Mutu Terpadu
}

Pengaruh Penerapan Manajemen Mutu Terpadu ( TQM ) Dalam Meningkatkan Kepuasan

Pelanggan.

\author{
Presti Putri Riwana \\ Universitas Negeri Padang \\ Indonesia \\ Email : \\ riwanaputripresti@gmail.c
}

om

\author{
Hade Afriansyah \\ Universitas Negeri Padang \\ Indonesia \\ Email : \\ hadeafriansyah@fip.ac.id
}

\author{
Rusdinal \\ Universitas Negeri Padang \\ Indonesia \\ Email : \\ rusdinalhar@yahoo.com
}

\begin{abstract}
ABSTRAK
Integrated quality management system can not only be used in the world of education but companies must also use education quality management, so that the quality of the products they produce can be good and meet customer satisfaction. therefore each company will compete to show its quality. companies carry out integrated quality management because they want to fix every single mistake that happens even if it is so small that consumers of the company will feel satisfied Control the quality of products including fees and market share, the company's reputation, product accountability, international implications. Expected to perform quality repairs, among others: Repair reputation, increased volume, price increases, production costs can be minimized so that the expected increase in company earnings
\end{abstract}

that are accompanied by the product expected by the customer on an ongoing base.

Keyword: Total Quality Management (TQM), customer satisfaction

\section{PENDAHULUAN}

Maju tidaknya suatu perusahaan sangat tergantung pada kualitas produk perusahaan tersebut. jika mutu suatu perusahaan itu mengalami stagnasi maka perusahaan itu akan terbelakang disegala bidang. setiap perusahaan dituntut untuk menjadikan organisasinya menuju persaingan bebas. Persaingan bebas atau yang dikenal globalisasi menjadikan organisasi berlomba-lomba meningkatkan mutu / kualitas seluruh sumber daya organisasinya. Dalam upaya meningkatkan mutu perusahaan salah satu usaha yang dapat dilakukan adalah dengan 
meningkatkan mutu produk yang ditawarkan sehingga produk yang ditawarkan bisa memenuhi harapan atau keinginan konsumen. Untuk bisa memenuhi harapan konsumen, maka perusahaan harus mampu meningkatkan kinerja agar produk yang dihaslkan memenuhi kualitas yang diharapkan. Salah satu langkah yang bisa dilakukan guna meningkatkan kinerja tersebut adalah dengan manajemen mutu terpadu yang merupakan suatu system guna meningkatkan kualitas produk yang berkelanjutan guna memenuhi kepuasan konsumen/pelanggan.

Untuk menjawab berbagai permasalahan yang ada di lingkungan bisnis tersebut terletak pada Manajemen mutu terpadu yang akan memberi solusi para professional untuk menjawab tantangan masa kini dan masa depan. Karena Manajemen Mutu Terpadu dapat digunakan untuk membangun aliansi antara pendidikan, bisnis dan pemerintah. Manajemen Mutu terpadu dapat membentuk masyarakat responsive terhadap perubahan tuntutan masyarakat di era globalisasi ini.

Manajemen Mutu Terpadu (TQM) pada segala bidang agar perusahaan secara terus menerus melakukan perbaikan - perbaikan guna peningkatan kualitas produk yang ditawarkan sesuai dengan harapan konsumen/pelanggan. Sebagaimana yang telah dikemukakan oleh Wuryanti yang menyatakan bahwa MMT merupakan aktivitas yang berusaha untuk mengoptimalkan daya saing organisasi melalui perbaikan yang terus menerus atas produk, jasa, manusia, proses, dan lingkungannya. Disamping itu, MMT merupakan sistem manajemen yang mengangkat kualitas sebagai strategi usaha dan berorientasi pada kepuasan pelanggan dengan melibatkan seluruh anggota organisasi.

Diharapkan dengan adanya manajemen mutu terpadu, semua harapan konsumen terpenuhi baik kualitas maupun kuantitas produk yang ditawarkan. Dengan terpenuhinya produk sesuai dengan kebutuhan konsumen secara terus menerus, diharapkan kelangsungan dan eksistensi perusahaan dalam persaingan global tercapai. Penelitian ini dharapkan memberikan kontribusi pentingnya manajemen mutu terpadi (TQM) dalam upaya meningkatkan layanan kepada konsumen/pelanggan. Upaya peningkatan layanan dengan memberikan produk yang sesuai harapan atau memenuhi kebutuhan konsumen secara berkelanjutan. Tujuan dari manajemen mutu terpadu adalah untuk mendapatkan hasil yang lebih baik secara terus menerus, perbaikan tanpa henti hingga tujuan organisasi dapat dicapai dan dengan melibatkan segenap komponen dalam organisasi.

\section{METODE}

Artikel ini disusun karna ingin mengetahui kepuasan pelanggan suatu perusahaan melalui penerapan TQM di Indonesia, terlebih dahulu mengumpulkan data - data baik itu kualitatif maupun kuantitatif dan bahan - bahan yang berhubungan dengan kajian yang akan ditinjau seperti bahan berikut ini, menurut Liana Rahardja 
(Wuryanti, 2013) terdapat Gugus Kendali Mutu (GKM) dalam upaya meningkatkan hasil yang lebih baik terus menerus. Dengan aktivitas GKM perusahaan akan mendapatkan karyawan yang benar-benar berani menghadapi persaingan dunia usaha. Terbukti bahwa salah satu factor keberhasilan industrialisasi di Jepang adalah penerapan GKM secara efektif. Karena keberhasilan ini, sejumlah negara industri maju dan sedang berkembang termasuk Indonesia, menerapkan GKM diperusahaan-perusahaan industri guna meningkatkan mutu, produktivitas dan daya saing. Maksud dari diadakannya pelatihan GKM adalah untuk menghasilkan suatu konsep baru untuk meningkatkan mutu dan dan produktivitas kerja industri/jasa., maka dari itu setelah mengumpulkan bahan dan data barulah kajian tersebut di tinjau dan dipelajari, selanjutnya penulis akan melakukan penyimpulan dari hasil yang telah dianalisisnya.

\section{KAJIAN TEORI DAN PEMBAHASAN}

A. Manajemen Mutu Terpadu Manajemen Mutu Terpadu ( Total Quality Management) dalam kontek pendidikan merupakan sebuah filosofi metodologi tentang perbaikan secara terus menerus, yang dapat memberikan seperangkat alat praktis kepada setiap institutsi pendidikan dalam memenuhi kebutuhan, keinginan,, dan harapan pelanggan, saat ini maupun masa yang akan datang. Sedangkan Santoso menyampaikan bahwa TQM merupakan suatu sistem manajemen yang mengangkat kualitas sebagai strategi usaha yang berorientasi pada kepuasan pelanggan dengan melibatkan seluruh anggota organisasi. Total Quality Management merupakan suatu pendekatan dalam menjalankan usaha yang mencoba untuk memaksimalkan daya saing organisasi melalui perbaikan terus menerus atas produk, jasa, manusia, tenaga kerja, proses, dan lingkungan.

\section{B. Tinjauan Penerapan TQM}

Dalam upaya meningkatkan kualitas dan produk yang sesuai harapan dan sesuai dengan kebutuhan pelanggan, maka perusahaan harus mampu diperlukan efisiensi dalam merealisasikan kegiatan dalam upaya pencapaian yang dimaksud yaitu produk yang bermutu, dengan jumlah yang diinginkan, sesuai kebutuhan para pelanggan yang membutuhkan. Perbaikanperbaikan yang dapat dilakukan penghematan di berbagai bidang hanya dapat dilakukan dalam suatu proses yang berlangsung panjang dan terus menerus dan berkesinambungan. Menurut Afriansyah (Afriansyah, 2019) dalam manajmen mutu terpadu sangat diperlukan pengawasan dan evaluasi, dimana juga diperlukan langkah - langkah seperti perencanaan, pelaksanaan barulah evaluasi hasil. 
Penelitian Penelitian Sutrisno (Wuryanti, 2013) hanya difokuskan kepada pelaksanaan kedelapan prinsip sistem manajemen mutu yang terdapat dalam ISO 9001:2000, yaitu fokus pelanggan, kepemimpinan, keterlibatan personel, pendekatan proses, pendekatan sistem terhadap manajemen, peningkatan berkesinambungan, pendekatanfaktual dalam pengambilan keputusan, dan hubungan dengan pemasok yang saling menguntungkan. Dan proses pengumpulan data dengan cara penyebaran kuesioner melalui media telekomunikasi dan e-mail, hasil penelitian menunjukkan bahwa penerapan manajemen mutu terpadu ISO 9000 yang tertinggi adalah pada prinsip Fokus pelanggan sedangkan yang terendah adalah pada prinsip pendekatan faktual dalam pengambilan keputusan, yang menunjukkan bahwa secara keseluruhan Penerapan manajemen mutu terpadu ISO 9000 di pulau Jawa tergolong sangat baik.

Penelitian lain pun, dengan tujuan penelitian yang dirumuskan yaitu untuk mengetahui seberapa besar pengaruh faktor-faktor determinan Manajemen Mutu Terpadu dalam kepemimpinan, pendidikan dan pelatihan, dukungan sumber daya manusia, komunikasi, pengakuan dan penghargaan, dan standar penilaian terhadap peningkatan kinerja sekolah dasar di kabupaten Purwakarta tahun 2003-2004.
Penelitian ini menggunakan metode survei penjelasan (explanatory survey method) dengan pendekatan kuantitatif melalui hubungan kausal dengan uji normalitas dan linieritas regresi dan perhitungan korelasi.Teknik pengumpulan data dilakukan melalui kuesioner dan studi dokumentasi. Hasil penelitian menyimpulkan bahwa gambaran mengenai faktor-faktor determinan manajemen mutu terpadu cukup tinggi dan keterkaitannya signifikan dan positif terhadap peningkatan kinerja sekolah dasar di kabupaten Purwakarta. Penelitian Nurul Chairani at all, 2011, diketahui bahwa penerapan TQM dapat memiliki dampak positif dan signifikan terhadap kinerja Perusahaan, kepemimpinan yang baik dapat meningkatkan perilaku produktif karyawan yang memoderasi hubungan antara TQM dengan kinerja perusahaan sehingga berpengaruh positif dan signifikan. Sementara kepemimpinan dan perilaku produktif karyawan tidak memiliki dampak positif dan signifikan terhadap kinerja perusahaan.

C. Kendala Penerapan Manajemen Mutu

Menurut Wuryanti (Wuryanti, 2013) merinci kendala dalam menerapkan Manajemen Mutu Terpadu adalah:

1. Lemahnya kepemimpinan dan delegasi wewenang manajemen Manajeme 
Mutu Terpadu akan berjalan sesuai dengan sasaran yang didinginkan jika pemimpin memiliki komitmen terhadap keterlibatan semua pihak. Artinya Manajemen Mutu Terpadu tidak akan berhasil manakala hanya diserahkan kepada tim tertentu yang ditunjuk oleh pimpinan, sementara pimpinan langsung menyerahkan program Manajeme Mutu Terpadu tersebut kepada tim yang ditunjuk. Dengan demikian pimpinan dapat mensosialisasikan perbaikan mutu yang dilakukan oleh pimpinan.

2. Mabuk tim Model ini bukan satusatunya, tetapi masih ada metode pengembangan lainnya.

3. Proses pengaturan yang tidak memadai Program Manajemen Mutu Terpadu harus mengilhami seluruh kegiatan. Bagi sekolah, maka seluruh kegiatan akademik (proses belajar mengajar) harus memperoleh perhatian dalam meningkatkan kualitasnya.

4. Pemilihan pendekatan yang sempit dan dogmatik Pendekatan yang sempit dan dogmatik tidak dapat secara fleksibel [memenuhi tuntutan perkembangan. Ini berarti ada kemandegan atau bahkan akan terjadi proses status quo. Pendekatan yang sempit tidak akan memberikan kesempatan bagi peningkatan Manajeme Mutu Terpadu. Manajeme Mutu Terpadu berorientasi pada pelanggan. Pelanggan memiliki kepuasan yang selalu berkembang. Oleh karenanya pendekatan dogmatik dan sempit tidak sesuai dengan kepuasan pelanggan.

5. Kurangnya dukungan sistem informasi dan alat ukur keberhasilan Lembaga atau oragnisasi termasuk sekolah amat sulit untuk mengetahui adanya peningkatan kualitas pelayanan di lembaganya, manakala tidak memiliki data dasar. Oleh karena itu setiap lembaga harus memiliki data dasar dan tolok ukur yang dicanangkan oleh lembaga yang bersangkutan. Dalam aplikasinya suatu perusahaan dituntut untuk mampu meningkatkan mutu produk yang ditawarkan dengan harapan produk yang ditawarkan mampu memenuhi kebutuahn pelanggan baik dari sisi kuantitas maupun sisi kualitas.

Dalam pembahasan ini menjelaskan bahwa pelanggan adalah salah satu faktor penentu dalam manajemen mutu terpadu dikarenakan pelanggan adalah faktor diluar organisasi yang akan menjadi stakeholder perusahaan/pengguna dari produk yang dihasilkan oleh perusahaan. Keberlanjutan yang diharapkan akan tercapai jika dalam 
pengendalian mutu produk yang

ditawarkan, dapat mempengaruhi organisasi dalam beberapa hal yaitu :Biaya dan pangsa pasar, Reputasi perusahaan, Pertanggungjawaban produk, Implikasi internasional. Diharapkan dapat melakukan perbaikan mutu, antara lain : Perbaikan reputasi, Peningkatan volume, Peningkatan harga. Harapan lain diantaranya dapat diminimalisir biaya produksi sehingga diharapkan terjadi peningkatan laba perusahaan.

D. Implementasi Total Quality Manajement di Sekolah.

Menurut Rusdinal(Rusdinal, 2015), Proses belajar yang baik adalah proses belajar yang bisa memudahkan siswa dalam memahami materi pelajaran yang diajarkan. Dalam proses belajar mengajar akan timbul suatu tanggapan dari siswa, tanggapan ini akan mempengaruhi perilaku siswa selanjutnya. Dengan kata lain tingkah laku siswa dalam belajar ditentukan oleh bagaimana tanggapannya tentang objek atau sesuatu yang diamati. Sehingga Layanan informasi yang diberikan kepada siswa dapat menggunakan berbagai metode, teknik, model pendekatan dalam strategi pembelajaran untuk mencapai tujuan pembelajaran (layanan informasi). Salah satu metode pembelajaran yang dapat digunakan pada layanan informasi dalam mengubah persepsi siswa tentang disiplin belajar adalah dengan mengkombinasikan metode ceramah, sosiodrama, dan diskusi. Sehingga apabila layanan informasi telah diberikan dengan baik kepada pelanggan yaitu peserta didik maka mutu pendidikan di sekolah tersebut akan baik pula.

Menurut Surahyo(Surahyo, 2015), sesuai dengan awal munculnya konsep Manajemen Mutu Terpadu ( Total Quality Manajement ) yang dikembangkan di lingkungan organisasi profit (perusahaan dan industri), maka dalam penerapan pengendalian manajemen mutu terpadu pada organisasi non profit seperti di sekolah sudah barang tentu tidak sama persis dengan yang diterapkan di dalam organisasi profit (dunia bisnis) pada umumnya, karena perlu disesuaikan dengan situasi dan kondisi yang ada, serta menyesuaikan dengan kebutuhan yang relevan dengan usaha peningkatan kualitas / mutu pendidikan di sekolah, di samping adanya perbedaan dalam menginterpretasikan pengertian kualitas / mutu sebagai terminologi kunci utama.

Total Quality Manajement (TQM) terfokus pada pengupayaan kepuasan pelanggan, dengan hasil produk yang berkualitas atau bermutu. Kata kunci quality atau mutu dalam Total Quality $\mathrm{M}$ a najement perlu diuraikan agar dapat digunakan dalam menjembatani pengimplentasiannya di lingkungan organisasi atau lembaga non profit khususnya di bidang pendidikan. 
Semuanya terfokus pada pemberian kepuasan pelanggan dalam memanfaatkan produk yang dihasilkan atau bahkan melebihi dari apa yang diinginkan oleh pelanggan. Total Quality Manajement dikembangkan tidak hanya sekedar sebagai konsep yang mengutamakan kualitas pada produk akhir, karena untuk mendapatkan produk yang berkualitas sangat dipengaruhi oleh beberapa faktor simultan, yaitu kualitas proses, lingkungan kerja dan sumber daya manusia yang mengahasilkan produk sebagaimana yang diinginkan dan dibutuhkan konsumennya. "Kualitas merupakan suatu kondisi dinamis yang berhubungan dengan produk, jasa, manusia, proses, dan lingkungan yang memenuhi atau melebihi harapan“.

IV. KESIMPULAN

Implementasi dari manajemen mutu terpadu atau total quality manajemen (TQM) pada beberapa perusahaan baik bidang jasa maupun barang secara umum memerikan mafaat yang positif bagi kelangsungan dan eksistensi perusahaan dalam persaingan global. Bahwa beberapa penelitian dengan berbagai jenis organisasi yang didapat memberikan kesimpulan bahwa faktor-faktor manajemen mutu terpadu memberikan pengaruh yang cukup signifikan terhadap kinerja perusahaan. Kinerja atau produktivitas perusahaan akan meningkat jika perusahaan melibatkan pelanggan sebagai salah satu faktor dalam pengambilan keputusan, hal ini dikarenakan pelanggan adalah stakeholder / pengguna dari produk yang kita tawarkan. Manajemen Mutu Terpadu atau Total Quality Management tidak hanya dilakukan dan diterapkan dalam perusahaan bisnis juga diterapkan dalam perusahaan non profit termasuk dunia pendidikan, hal ini dikarenakan telah terbukti keberhasilannya dalam mempertahankan dan mengembangkan eksistensinya masing-masing dalam kondisi bisnis yang kompetitif. Manajemen mutu terpadu dapat diimplementasikan di perusahaan, dengan seluruh sumber daya yang ada ikut mendukung tercapainya dan pemenuhan kebutuhan pelanggan sesuai harapan pelanggan. Sehingga manajemen mutu terpadu tidak hanya dititik beratkan pada kualitas produk yang dapat memenuhi kebutuhan pelanggan dengan berbagai selera yang ada, namun manajemen mutu terpadu juga dapat terwujud dengan adanya dukungan kepemimpinan yang ada.

\section{Daftar Pustaka}

\section{Afriansyah, H. (2019). MANAJEMEN MUTU TERPADU. Jurnal Ilmiah Ilmu Pendidikan, 1. https://doi.org/https://doi.org/DOI 10.17605/OSF.IO/JXCQY}

Rusdinal. (2015). Efektivitas Layanan Informasi yang Mengkombinasikan Metode Ceramah, Sosiodrama, dan Diskusi dalam Merubah 
Persepsi Siswa Tentang Disiplin Belajar.

Konselor, 4(1), 1-9. Retrieved from

http://ejournal.unp.ac.id/index.php/konselor/a

rticle/view/6453/5103

Surahyo. (2015). IMPLEMENTASI

MANAJEMEN MUTU TERPADU DALAM

SISTEM PENDIDIKAN,

PERMASALAHAN DAN

PEMECAHANNYA. Jurnal Didaktika

Islamika, 5(1), 1-11. Retrieved from

http://stitmkendal.ac.id/docs/jurnal/implemen

tasi_manajmen_mutu_terpadu_dalam_sistem

_pendidikan_permasalahan_dan_pemecahan

nya_0.pdf

Wuryanti, L. (2013). Tinjauan Manajemen Mutu

Terpadu (Total Quality Management) Dalam

Meningkatkan Kepuasan Pelanggan. Jurnal

Riset Akuntansi Dan Manajemen, 2(2), 1-7.

Retrieved from http://malahayati.ac.id/wp-

content/uploads/2016/02/LESTARI-2-2-98-

104.pdf

Afriansyah, H. (2019). MANAJEMEN

MUTU

TERPADU.1.http://doi.org/10.17605/OSF.

IO/JXCQY 